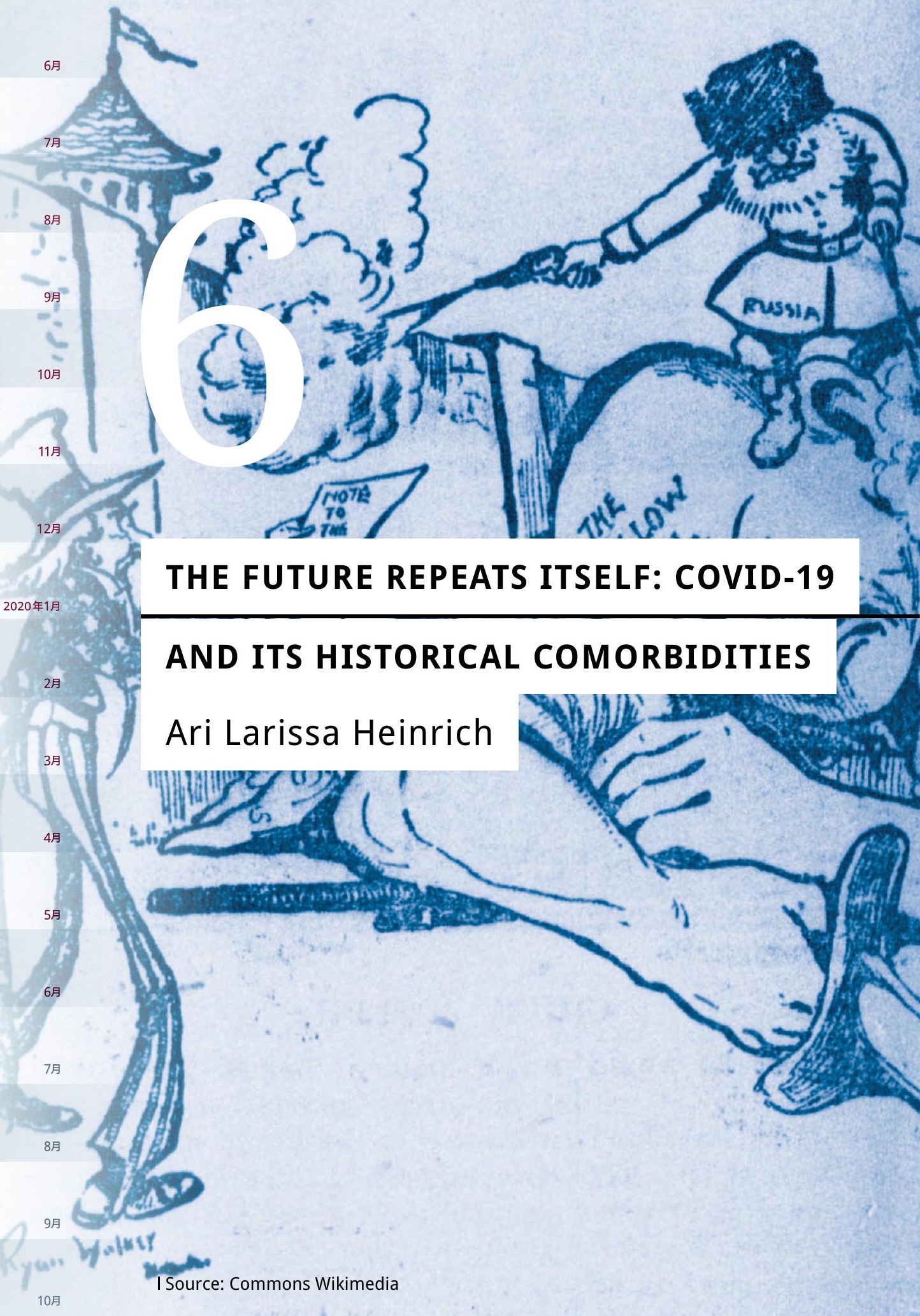




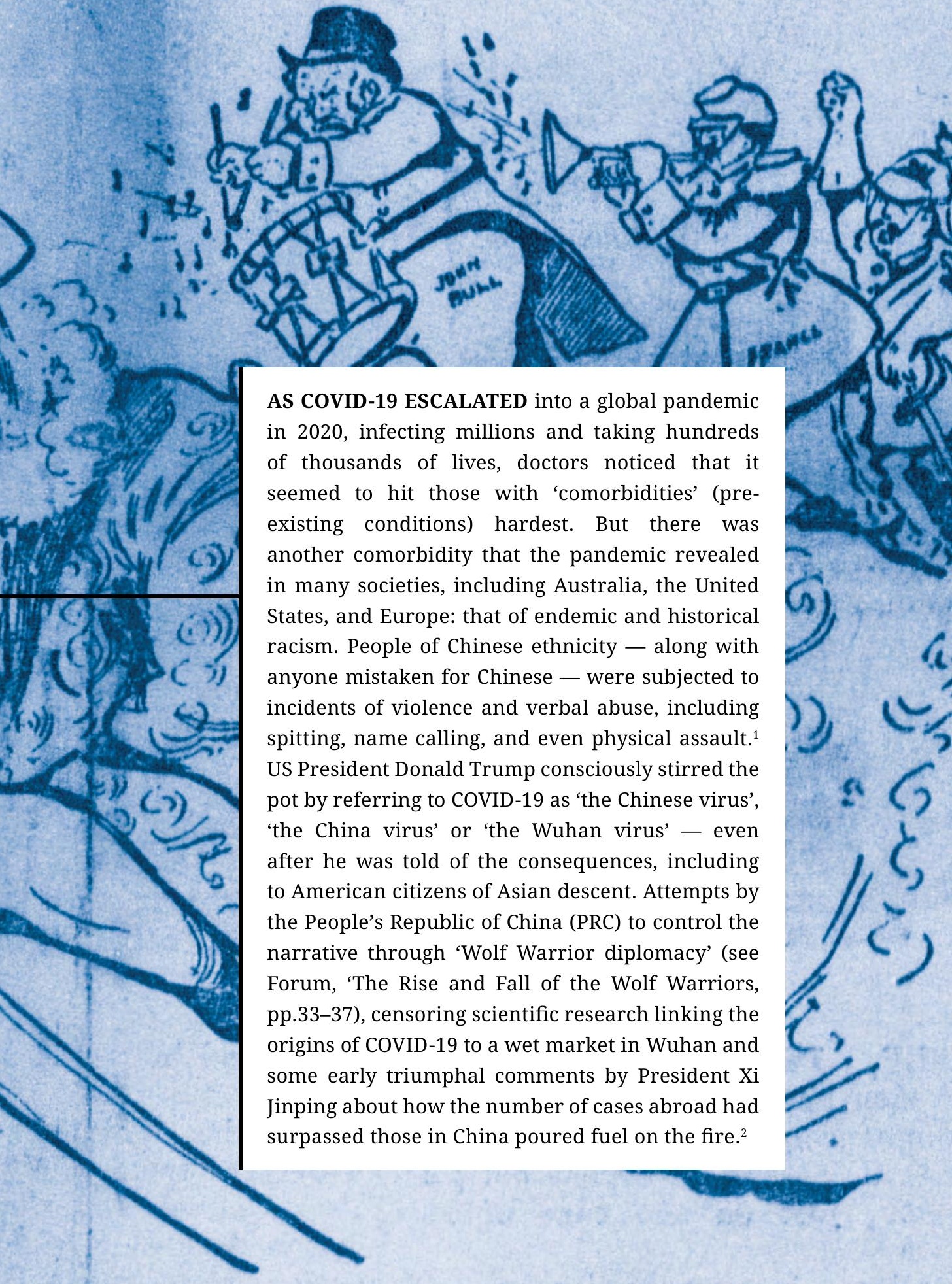


With Trump announcing that the US, which provides 15 percent of the funding to the World Health Organization (WHO), was withdrawing from the organisation because of perceived pro-China bias, he extended the pain to all those countries and people who rely on the WHO to help them combat such diseases as polio and malaria.

The intensity of this eruption of popular anti-Asian racism in the US, Europe, and Australia draws on deeply entrenched stereotypes that date back more than 200 years. These unfairly characterise Chinese people as uniquely vulnerable to certain kinds of illness and as having dietary customs and a lack of hygiene that create a cultural predisposition towards disease. ${ }^{3}$ They can be traced with remarkable precision to politically charged exchanges as far back as the late eighteenth century. Understanding their evolution and circulation can help defuse some of the vitriol of racist attacks against Chinese and other Asian people today and free us to focus instead on the real common enemy in the fight against COVID-19: the unequal distribution of wealth and power that results in the disproportionate impact of the disease on communities disenfranchised across categories of race, class, gender, location, and the like.

Responses to the surge in anti-Chinese (and anti-Asian) racism rarely refer to such structural issues. Rather, they tend to include pleas for self-reflection and civility from governments, compensatory generosity, and statements by Asian-Americans, Asian-Australians, and others, and expressions of solidarity from other people of colour or minorities. As early as mid-January, scholars from around the world began gathering and circulating articles, bibliographies, and curriculums for educators who wish to contextualise the eruption of pandemic-related racism in light of persistent anti-Asian myths of the 'yellow peril'. ${ }^{4}$ Even before COVID-19, other scholars had been working to address the plight of Chinese international students in Australia, for instance, who face everyday racism, on top of other challenges including loneliness, alienation, and cross-cultural misunderstanding. ${ }^{5}$ (See Chapter 10, 'Chinese Students Abroad in the Time of Pandemic: An Australian View’, pp.291-303.) 


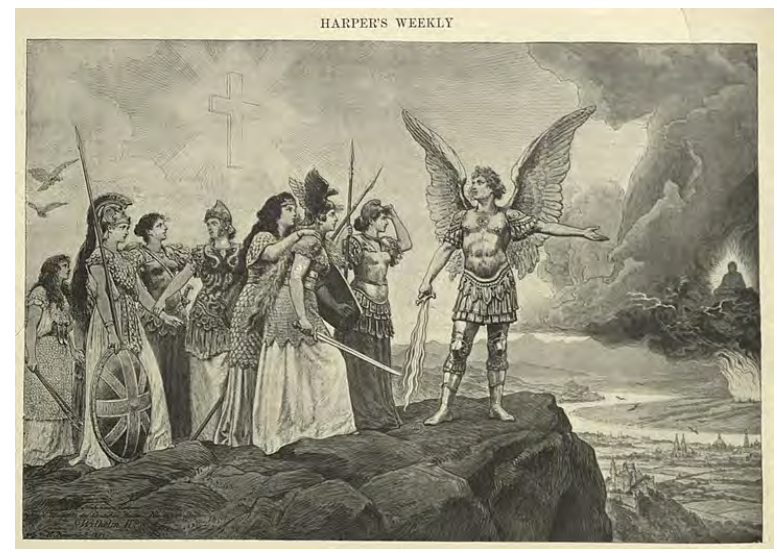

While the recent outbreak of anti-Asian racism may appear to be specific to the situation of a pandemic with apparent origins in a live animal market in China, this anti-Asian sentiment and violence (like other racism and anti-Semitism) bubble just below the surface of economic instability. The COVID-19 pandemic has not caused racist violence; rather, it has tapped into long-established streams of anti-Asian aggression. ${ }^{6}$ What, then, are some of the specific historical tributaries that feed into these streams? From where do the perceptions of Chinese propensity towards pathology actually come?

\section{Nineteenth-Century Fake News}

Ancient falsehoods and modern truths relate to each other like the two revolutions of a single spiral.

— Bruno Latour, The Pasteurization of France ${ }^{7}$

Many of the roots of current anti-Asian racism lie in late eighteenth- and nineteenth-century misinformation about Chinese cultural practices that were communicated down the years in a game of transhistorical telephone. An archetypal and stubbornly persistent characterisation of 
Chinese people specifically and, later, Asians more generally has them posing a collective existential threat of 'yellow peril' to the West. ${ }^{8}$ The idea has its roots in the Chinese resistance to Western imperialism that came to a head with the Boxer Uprising at the turn of the twentieth century, when thousands of fighters stormed missionary outposts and eventually laid siege to Beijing's Legation Quarter. While disease sometimes fits under the larger umbrella of 'yellow peril' in Western characterisations of 'Asian' threats, epidemics often generate their own individual stereotypes.

Take smallpox as an example - the disease that everyone loves to blame on someone else. Like cholera or the bubonic plague, smallpox has been laid variously at the door of India, Turkey, the Middle East, and China. From the early 1800s, many Europeans and Americans believed that China was the 'cradle of smallpox' - an idea circulated by numerous missionary journals, travelogues, bulletins, and official reports from that time onwards. For example, as travel writer Charles Toogood Downing stated in 1838:

This dreadful malady is supposed to have originated among the Chinese, and to have spread westward in a gradual manner among the natives of Western Asia, until it became as prevalent with the people of Europe, as among those of the Centre Kingdom. The disease then ran its frightful course, unchecked by the ingenuity and resources of man; spreading dismay and horror wherever it appeared, and blighting the loveliness and beauty of the fairest works of the creation. ${ }^{9}$

Downing claimed that the Chinese had invented the practice of inoculation. He continued:

As if in some measure to compensate the nations of the west for the dreadful gift which they had bestowed, the Chinese discovered, towards the close of the tenth century, the mitigating effects of inoculation. This practice, by which it was vainly hoped that the original disease might 
be entirely eradicated, followed the same course, and soon became common as far as the shores of the Atlantic. ${ }^{10}$

Downing got this information from a single - and singularly unreliable - source: an eighteenth-century essay by the French Jesuit missionary Father Pierre Martial Cibot called 'De la petite vérole' ('On Smallpox'). Cibot composed the essay in Beijing in the late 1760s, but it did not reach Paris until 1772. It begins with a punchy proclamation that smallpox had existed in China for 3,000 years and claims to summarise 'many very knowledgeable and very boring [Chinese] essays on the origin and the cause of smallpox'. Cibot dismissed unambiguously what he viewed as the 'pathetic stupidity' of Chinese medicine, described its 'lunacy and inconsistency' and declared the history of Chinese medicine to have been obscured by 'clouds of idiocy'. An earlier (1726) report on smallpox by another French Jesuit in China, Father François Xavier D’Entrecolles, ${ }^{11}$ had adopted a more neutral tone. Where D'Entrecolles had investigated Chinese inoculation practices with an eye towards finding something useful for Europe, Cibot reserved his most acidic critique for the practice.

The management of smallpox and the practice of inoculation were actually quite advanced in China, especially compared with France during the same period. As early as 1622, the Manchus - a people from
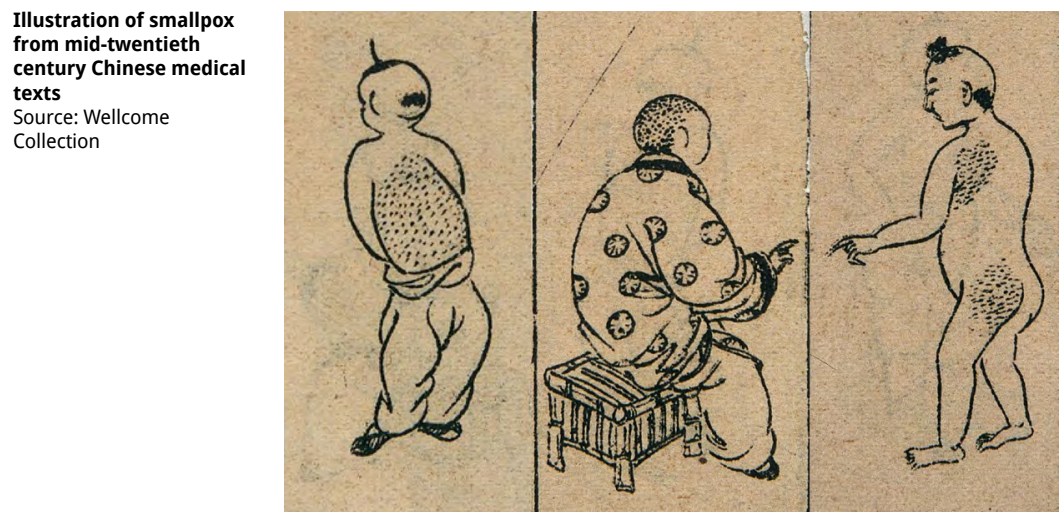


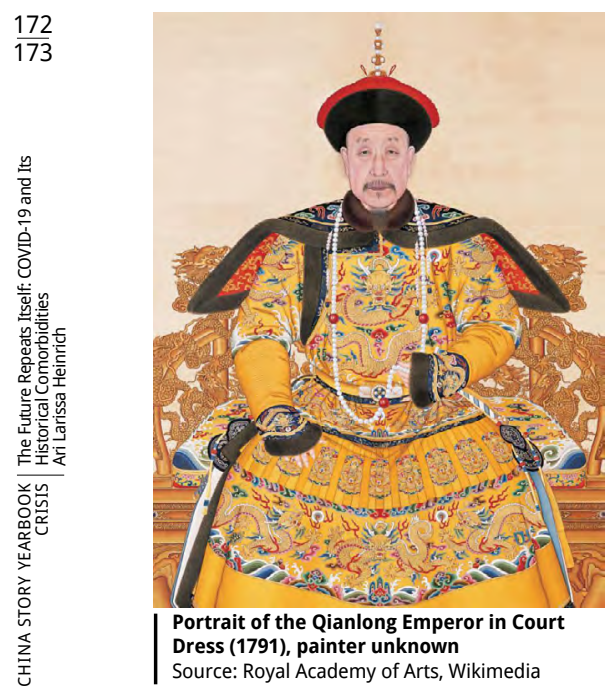

north of the Great Walls who would soon conquer the Ming and establish the Qing dynasty - had already implemented smallpox reporting systems within the context of the 'banners' that were the basis of social, political, and military organisation. The system required squad leaders to report anyone showing symptoms so they could be quarantined. Clear guidelines also ensured safe interactions with non-Chinese and Mongolian dignitaries, protected the emperor during audiences and applied to funeral rites and the stationing of military personnel (for example, sending officers who had acquired immunity to smallpox to regions where the disease was active). The Manchus also set up strictly maintained bidousuo 避痘所 ('smallpox avoidance centres') - quarantine centres to which the emperor might retreat during the seasons in which smallpox ran rampant.

Both the Kangxi (r. 1661-1722) and Qianlong (r. 1735-1796) emperors were inoculated against the disease, as were other members of the imperial retinue. In 1739, Qianlong even sponsored the compilation of an imperial medical anthology that contained a special section devoted to smallpox diagnosis and inoculation - the very text upon which Cibot later claimed to base much of 'De la petite vérole'. This imperially subsidised reference work not only included detailed illustrations to aid specific diagnoses, but also summarised existing treatises on smallpox and provided precise descriptions of how to prepare smallpox matter for inoculation, instructions for creating the optimal conditions under which to perform inoculation, descriptions of adverse reactions to inoculation, and suggestions for post-procedure care. 
Given this advanced institutional and pragmatic response to smallpox and the practice of inoculation in China, why would Cibot choose to represent the Chinese situation so pessimistically? It came down to politics. When Cibot left France for Beijing in 1758, inoculation was becoming the subject of heated controversy between the Church and Enlightenment thinkers. This was because inoculation (to be distinguished from the later practice of vaccination) used material from the disease itself to stimulate an immune response. Although it sometimes caused full-blown smallpox, more often, it successfully immunised the recipient against the disease. At the time, the Church considered disease to be a divine plague or scourge. Voltaire was among the French intellectuals who favoured inoculation, but the Church believed it interfered with divine will and, by 1763, banned the practice. The controversy ended abruptly in 1774, when Louis XVI, having witnessed Louis XV's gruesome and untimely death from smallpox, was himself inoculated.

Based on his knowledge of the political situation in France at the time of his departure for China, Cibot realised that if he represented Chinese responses to the disease in too positive a light, he risked giving ammunition to Enlightenment thinkers who were arguing against the stance of the Church. He chose to invert the narrative by critiquing Chinese medical practice in general and using China's success in establishing institutionalised preventive measures around smallpox as 'evidence' of Chinese vulnerability to the disease. As the meticulous medical archivist and plague specialist Wu Lien-teh noted in the 1930s, Cibot's essay - particularly his claim that smallpox had existed in China for three millennia - was subsequently 'often repeated', including 'in some quite modern compilations', such that 'China was even considered as the cradle of smallpox'. ${ }^{12}$ A reference to Cibot's eighteenth-century essay made it unchallenged as the source of a footnote on China in Donald Hopkins's (otherwise) definitive 2002 world history, The Greatest Killer: Smallpox in History. 


\section{Pathological Racism}

The narrative of smallpox in China contributed to the evolution of an even broader and more insidious stereotype linking Chinese identity to pathology: the notion that China was the 'sick man of Asia'. According to this idea, China and Chinese people are uniquely susceptible to ailments, be they corporeal, cultural or symbolic (for example, ailments of the body politic). Coinciding with the development of influential pseudoscience about 'race' in the late nineteenth century, these notions gained momentum. By the early twentieth century, China became known not only as the 'cradle of smallpox' and the 'sick man of Asia', but also as 'the original home of the plague', a source of cholera ('the pestilence of the East') and a place where men were constitutionally weak. ${ }^{13}$ Imperialist powers perceived themselves to have a 'civilising' mission. It helped to justify occupation and exploitation if the occupied and exploited were painted as inferior but capable of improvement through the paternalistic intervention of the occupier and exploiter.

In Cibot's time, China still occupied a dominant position in the European psyche in relation to trade and culture. Many Europeans viewed China not just as a desirable trading partner, with its magnificent porcelain wares, teas, spices, and other goods that were highly sought after - even if China was not interested in anything the West had to offer. It was also seen by some, including Voltaire, as a potential source of medical knowledge and positive models of government. China's status plunged after Britain and France defeated it in the Opium Wars so-called because they were waged so that opium could be exported to China - in the middle of the nineteenth century. As European and American imperial powers made advancements in medical, martial, industrial, and agricultural technologies, they also formalised colonial labour practices, exploiting the global slave trade and trans-Pacific commerce of 'coolie' workers for such projects as railway building in the US and gold digging in Australia. ${ }^{14}$ The accumulation of wealth became 


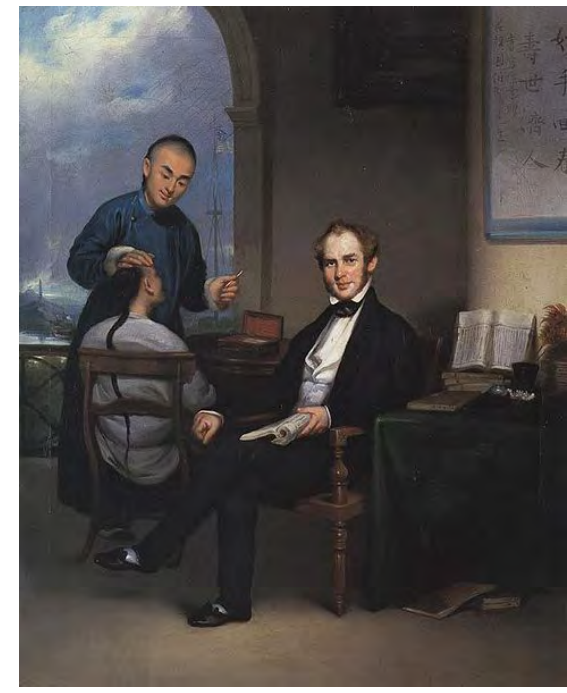

| Dr Peter Parker (c.1840s) by Lan Qua (1801-1860) Source: Massachusetts Institute of Technology

Visualizing Cultures even more explicitly enmeshed with the expansion of religious dogma and colonial enterprise, which in turn had consequences for perceptions of the origins of various pathologies. This coincidence of technological, economic, and political expansion created a perfect storm of conditions for the typecasting of Chinese and other non-Western groups. China emerged from this period not as a source of cures, but as a source of pathologies. $\begin{array}{crr}\text { A } & \text { particularly } & \text { vivid } \\ \text { example } & \text { concerns } & \text { the }\end{array}$ opened a hospital in Guangzhou. Like other missionary doctors at this time, Parker sought to use Western medicine to win converts. He found that relatively simple procedures, such as cataract removal, could yield results with biblical resonance - bringing sight to the blind, for example. To illustrate some of his more spectacular cases, Parker hired the respected Cantonese painter Lam Qua 關喬昌 (1801-1860) to create a series of full-colour portraits of more than eighty of his patients, including several 'before and after' images showing the dramatic effects of surgical intervention. ${ }^{15}$ The artist's work was stunning. Compared with the limited images that could be produced by photography, which was still in its infancy, Lam Qua's detailed, full-size portraits in oil of Parker's patients were vibrant and lifelike. These portraits were as much sensitive portrayals of individual Chinese people as they were portrayals of unique medical conditions. 
Some of Lam Qua's paintings were hung in the receiving room of the missionary-run hospital for prospective patients and their families to view; however, the majority accompanied Parker on a visit back to the US and Europe in 1840-1841, where he used them to petition ecclesiastical organisations and government bodies for funding to support his work. Parker pleaded his cause to influential people, from the American presidents William Henry Harrison and Martin Van Buren to the king and queen of France. He also exhibited Lam Qua's paintings in Boston, New Haven, New York, Philadelphia, Salem, and Guy's Hospital in London. Removed from their original context (and in the absence of equally compelling portraits of everyday healthy Chinese people), the striking paintings of gross pathology not only provided potential funders with compelling evidence of China's need for medical intervention, but also conveyed a sense that Chinese people were disproportionately vulnerable to frightening illnesses and all the more in need of spiritual salvation.

There were other, later chapters in this story, in which 'yellow peril' rhetoric blended with that of imagining Chinese people as carriers of disease, including during the Cold War, when communism was portrayed as a contagious and potentially fatal disease of the spirit.

In the age of COVID-19, such examples make the current rise of demagoguery, the politicisation of vaccination and the challenge of sorting through misinformation about the origins of the pandemic feel uncannily familiar. What can we learn about the economic motivations behind the proliferation of fake news about political opponents in a time of intensified trade wars? The old French adage that 'the more things change, the more they stay the same' seems to be more apt today than ever. It can take years or even centuries for the truth about a given circumstance to emerge. Before rushing to translate our anxiety about the latest 'dreadful malady' into aggression against those we perceive to be responsible, we should first ask who stands to benefit 
from this racialised discourse. History suggests that such rhetoric has serious consequences.

When a president of the US refers to COVID-19 as 'the China virus', he draws directly on a longstanding stereotype of Chinese pathology that has roots not in medical evidence but in old political, commercial, and religious rivalries. The history behind this stereotype - including its connection to the emergence of the 'sick man of Asia' stereotype - also helps explain why China is so deeply invested in 'controlling the narrative' of COVID-19. However, in spite of President Trump's escalation of dangerous myths about Chinese pathology, at least we can be grateful to him for shining the spotlight on what is really behind this particular outbreak of anti-Asian animosity - that is, the enduring (and all too contagious) virus: greed. 
This text is taken from China Story Yearbook: Crisis, edited by Jane Golley and Linda Jaivin with Sharon Strange, published 2021 by ANU Press, The Australian National University, Canberra, Australia.

doi.org/10.22459/CSY.2021.06 